\title{
ПОДБОР СОРТОВ САЛАТА ЛИСТОВОГО ДЛЯ ВЫРАЩИВАНИЯ В ЗИМНИХ ТЕПЛИЦАХ В УСЛОВИЯХ ЦЕНТРАЛЬНОЙ ЯКУТИИ
}

\author{
И.П. Иванова \\ преподаватель среднего профессионального образования \\ кафедры агрономии \\ Октёмский филиал ФГБОУ ВО Якутская ГСХА, с. Октёмцы
}

В последнее время отмечается повышение интереса к технологии выращивания листового салата. В связи с этим приобрели актуальность исследования по анализу потребительского спроса и подбору сортов листового салата для выращивания в зимних теплицах методом подтопления в условиях Центральной Якутии.

О том, что растения могут расти и нормально развиваться на искусственных питательных средах, известно давно. Впервые растение на водном растворе химически чистых солей было выращено

Сорт листового салата, зимняя теплица, метод подтопления, урожайность

Varieties of the leaf lettuce, heated houses, flooding method, yield в 1559 г. немецким агрохимиком Ф. Кнопиом. В России выращивание растений в искусственных условиях осуществил великий русский учёный К.А. Тимирязев. В 1896 г. в Нижнем Новгороде им были продемонстрированы знаменитые опыты по выращиванию растений без почвы, в физиологических растворах. К.А. Тимирязев подчёркивал, что по мере развития общества и его средств производства, культура растений без польз будет приобретать всё большее распространение, как способ интенсивного производства продуктов растительного происхождения [1].

Технология выращивания овощей методом подтопления - это способ выращивания растений на искусственных средах без почвы в контейнерах, размеры которых подбираются в зависимости от овощной культуры. Питание растения получают из подготовленного раствора, поступающего на рассадный стол $[2,3]$.

Цель исследований - подбор сортов листового салата для выращивания в зимних теплицах методом подтопления.

Задачи исследований:

1. Изучить фенологические особенности сортов салата.

2. Сравнить урожайность и качественные показатели сортов салата листового.

3. Оценить устойчивость сортов салата к основным болезням и вредителям.

4. Рассчитать экономическую эффективность выращивания салата.

\section{Место и методика исследований}

Опыты проводились в зимней остеклённой теплице, которая находится в с. Чапаево Хангаласского улуса. Теплица общей пло-

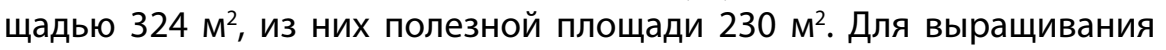
рассады используется органический субстрат на основе верхового сфагнового торфа, заправленный удобрениями и нейтрализо- 
ванный до $\mathrm{pH}$ 5,5-6,0. В субстрат перед применением добавляется в качестве рыхлящего вещества агроперлит в соотношении 2:1. Рассада помещена в контейнеры на 64 и 54 ячейки, а для её выращивания до товарной спелости используются контейнеры с 8-ю отверстиями, в которые вставляются стаканчики с рассадой, размещаемые в рассадной зоне [2, 4].

В ходе исследованийпроводились наблюдения по фенологическим показателям роста и развития, учитывались биометрические показатели, урожайность и товарность продукции определялись по пробным срезам, определялись качественные показатели. Сравнивались вкусовые особенности каждого сорта. Был проведён маркетинговый анализ.

В опытах изучалось пять сортов и гибридов салата листового: Дубачек, Изумрудное кружево, Фанли F1, Азарт, Лифли F1.

Повторность опытов четырёхкратная. Размещение кассет систематическое. Размер кассет $0,6 \times 0,5$ м $\left(0,3 \mathrm{~m}^{3}\right)$. Размер опытной делянки 8 кассет, или 2,4 м², где размещено по 64 растения. В одной кассете размещаются в шахматном порядке 8 стаканчиков с растениями $[2,4]$.

Фенологические наблюдения, определение качества продукции проводились по методике Госкомиссии по испытанию и охране селекционных достижений Российской Федерации.
Урожайные данные были обработаны по методике Б.А. Доспехова [5].

Экономическая эффективность рассчитывалась по нормативно-затратному методу.

\section{Результаты}

Результаты фенологических наблюдений

Посев был произведён 10 августа. Всходы были дружные, дата полных всходов отмечена 13 августа. Наиболее скороспелыми были сорта Изумрудное кружево и Дубачек. Период от полных всходов до товарной спелости составляет 40 дней. Сорт Азарт, гибриды Лифли, Фанлиза достигли товарной спелости за 45 дней.

Результаты биометрических исследований

Установили, что по биометрическим показателям сорта салата значительно различаются количеством листьев (от 10 шт. у сорта Азарт до 15 у сорта Фанли).

Наиболее высокие растения были отмечены у сортов Азарт и Изумрудное кружево, 27 и 32 см соответственно. У сорта Лифли самые высокие растения составляли 16 см (табл. 1).

Диаметр розеток листьев сортов салата также значительно различался. Так, наибольший диаметр имели розетки листьев у сорта Дубачек и гибрида Лифли, 22 и 19 см соответственно. Наименьший диаметр имели розетки листьев сорта Азарт и гибрида Фанли - 15 и 17 соответственно.

Таблица 1 - Биометрические показатели сортов салата листового (среднее за 2016-2017 гг.)

\begin{tabular}{|l|c|c|c|c|}
\hline \multicolumn{1}{|c|}{ Сорт } & Количество листьев, шт. & Высота растений, см & Диаметр растений, см & Масса растения, г \\
\hline Лифли F1 & 14 & 16 & 19 & 125 \\
\hline Азарт & 10 & 27 & 15 & 105 \\
\hline Изумрудное кружево & 13 & 32 & 16 & 110 \\
\hline Дубачек & 13 & 22 & 22 & 155 \\
\hline Фанли F1 & 15 & 18 & 17 & 122 \\
\hline
\end{tabular}

Максимальная масса одного растения отмечена у сорта Дубачек (155 г), наименьшая масса у сорта Азарт (105 г).

Устойчивость сортов салата листового $к$ основным болезням и вредителям

При выращивании салата листового были отмечены следующие болезни: корневые гнили и аскохитох. Из вредителей отмечалась только минирующая муха.

Больше всего корневыми гнилями был повреждён сорт Изумрудное кружево (1,11\%), меньше всего - сорт Дубачек (0,30\%). Остальные сорта и гибриды заняли промежуточное положение (0,31-0,42\%). Аскохитозом меньше всего поражались сорт Дубачек и гибрид Фанли $(0,21$ и 0,26\% соответственно).

Повреждения минирующей мухой незначительны и зависели от сортовых особенностей салата (поражённость колебалась от 0,48 до 0,56\% растений).

Урожайные данные сортов салата листового

Урожайность сортов салата приведена в таблице 2. За стандарт был принят сорт Азарт как отечественный и наиболее распространённый. 
Таблица 2 - Урожайность сортов салата листового (среднее за 2016-2017 гг.), кг/м²

\begin{tabular}{|c|c|c|c|c|c|c|}
\hline \multirow{2}{*}{ Сорт } & \multicolumn{4}{|c|}{ Повторность } & \multirow{2}{*}{ 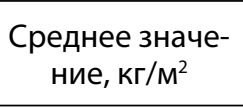 } & \multirow{2}{*}{ Отклонение, +,- } \\
\hline & 1 & 2 & 3 & 4 & & \\
\hline Лифли F1 & 3,05 & 3,14 & 2,88 & 2,63 & 2,93 & St. \\
\hline Азарт & 3,02 & 3,42 & 3,30 & 3,66 & 3,35 & $+0,42$ \\
\hline Изумрудное кружево & 2,91 & 2,88 & 2,75 & 2,76 & 2,82 & $-0,11$ \\
\hline Дубачек & 4,06 & 4,12 & 4,25 & 4,17 & 4,15 & $+1,22$ \\
\hline Фанли F1 & 3,32 & 3,26 & 3,19 & 3,33 & 3,28 & $+0,35$ \\
\hline $\mathrm{HCP}_{05}$ & \multicolumn{6}{|c|}{$0,37-0,40$} \\
\hline
\end{tabular}

Все испытываемые сорта и гибриды, кроме сорта Изумрудное кружево, обеспечили достоверную прибавку урожая. Наибольшую урожайность обеспечил сорт Дубачек $(1,22$ кг/м²), самую низкую урожайность - сорт Изумрудное кружево $\left(2,82 \mathrm{~K} \Gamma / \mathrm{M}^{2}\right)$.

С точки зрения потребителей имеет значение цвет листьев салата, их упругость, величина, вкусовые качества листьев салата. Анализ листьев салата по этим показателям приведён в таблице 3.

При анализе потребительского спроса установлено, что наибольшим спросом пользуются сорта более интенсивно окрашенные, т.е. гибрид Лифли.
Также наиболее востребованными оказались растения с более плотными листьями - салат сорта Азарт. По вкусовым качествам высокие баллы имели сорта Дубачек и Изумрудное кружево, хотя гибрид Лифли и сорт Азарт также считаются достаточно вкусными и не имеют резкой горечи.

Оценка сортов потребителями показала, что наибольшим спросом пользуется сорт Азарт и гибрид Фанли.

Наибольшая товарность урожая отмечена у сорта Азарт и гибридов Лифли и Фанли (95, 95 и 96\% соответственно).

Самая низкая товарность урожая отмечена у сорта Изумрудное кружево (87\%).

Таблица 3 - Качественные показатели сортов салата листового

\begin{tabular}{|l|c|c|c|c|}
\hline \multicolumn{1}{|c|}{ Сорт } & Цвет листьев & $\begin{array}{c}\text { Плотность } \\
\text { листьев, г/см }{ }^{2}\end{array}$ & $\begin{array}{c}\text { Вкусовая оценка, } \\
\text { балл }\end{array}$ & $\begin{array}{c}\text { Tоварность } \\
\text { урожая, \% }\end{array}$ \\
\hline Лифли F1 & зелёный & 0,53 & 4,8 & 95 \\
\hline Азарт & светло-зелёный & 0,59 & 4,8 & 96 \\
\hline Изумрудное кружево & светло-салатовый & 0,33 & 5,0 & 87 \\
\hline Дубачек & светло-салатовый & 0,35 & 5,0 & 89 \\
\hline Фанли F1 & светло-зелёный & 0,49 & 4,6 & 95 \\
\hline
\end{tabular}

\section{Вывод}

Установлено, что наиболее скороспелыми являются сорта Изумрудное кружево и Дубачек. Наибольшие показатели следующие: количество листьев - у гибрида Фанли; эффективность выращивания-у сорта Дубачек (урожайность 4,15 кг/M²); масса одного растения - у сорта Дубачек
(155 г). Данный сорт также является скороспелым и наиболее устойчивым к основным болезням листового салата.

Таким образом, из изученных пяти сортов, наиболее урожайным, скороспелым и устойчивым к основным болезням является сорт Дубачек.

\section{Лumepamypa}

1. Гиль, Л.С. Современное овощеводство закрытого и открытого грунта [Текст]: Практическое руководство / Л.С. Гиль, А.И. Пашковский, Л.Т. Сулима. - Житомир: Рута, 2012. - 468 с.

2. Антипова, О.В. Технология выращивания овощных культур методом подтопления [Текст]: Агротехнические рекомендации / О.В. Антипова // Гавриш. - 2006. - №2. - С. 6-11. 
3. Современное овощеводство закрытого и открытого грунта. Практическое руководство [Электронный ресурс] // WWW.BIBLIOTEKAR.RU. - Режим доступа: www.bibliotekar.ru/7-ovoschi/34.htm/ (дата обращения: 16.04.2019 г.)

4. Технология выращивания овощных культур на торфяных и минераловатных субстратах (малообъемная гидропоника) [Текст]: Рекомендации / Гос. агропром. ком. СССР. - М.: Агропромиздат, 1988. - 78 с.: ил.

5. Доспехов, Б.А. Методика полевого опыта [Текст] / Б.А. Доспехов. - 5-е изд., перераб. и доп. - М.: Агропромиздат, 1985. - 351 с.

\section{References}

1. Gil', L.S. Sovremennoe ovoshhevodstvo zakrytogo i otkrytogo grunta [Tekst]: Prakticheskoe rukovodstvo / L.S. Gil', A.I. Pashkovskij, L.T. Sulima. - Zhitomir: Ruta, 2012. - 468 s.

2. Antipova, O.V. Tehnologija vyrashhivanija ovoshhnyh kul'tur metodom podtoplenija [Tekst]: Agrotehnicheskie rekomendacii / O.V. Antipova // Gavrish. - 2006. - № 2. - S. 6-11.

3. Sovremennoe ovoshhevodstvo zakrytogo i otkrytogo grunta. Prakticheskoe rukovodstvo [Jelektronnyj resurs] // WWW.BIBLIOTEKAR.RU. - Rezhim dostupa: www.bibliotekar.ru/7-ovoschi/34.htm/ (data obrashhenija: 16.04.2019 g.).

4. Tehnologija vyrashhivanija ovoshhnyh kul'tur na torfjanyh i mineralovatnyh substratah (maloob\#emnaja gidroponika) [Tekst]: Rekomendacii / Gos. agroprom. kom. SSSR. - M.: Agropromizdat, 1988. - 78 s.. il.

5. Dospekhov, B.A. Metodika polevogo opyta [Tekst] / B.A. Dospekhov. - 5-e izd., pererab. i dop. M.: Agropromizdat, 1985. $-351 \mathrm{~s}$.

\section{ОБЫЯВЛЕНИЕ}

В издательстве ФГБОУ ВО Ярославская ГСХА в 2017 г. вышла монография

\section{Р.В. Тамаровой, Н.Н. Канарейкиной}

\section{«ПОВЫШЕНИЕ ЭФФЕКТИВНОСТИ ИСПОЛЬЗОВАНИЯ МОЛОЧНОГО СКОТА НА КРУПНОМ КОМПЛЕКСЕ С БЕСПРИВЯЗНЫМ СОДЕРЖАНИЕМ КОРОВ»}

В монографии представлен опыт создания высокопродуктивного племенного стада на базе товарного в условиях комплекса с беспривязным содержанием коров. Рассмотрены вопросы адаптации, здоровья и сохранности животных, причины выбытия их из стада, кормления и выращивания молодняка, молочная продуктивность, технологические качества, воспроизводительная способность, экономическая эффективность хозяйственного использования коров разных генетических групп, отечественной и импортной селекции. Исследования проводились с использованием научных методик и пакета компьютерных программ. Все количественные показатели биометрически обработаны, с выявлением достоверности разности при трёх уровнях вероятности. На основании полученных результатов сделаны обоснованные выводы и предложения производству.

Монография предназначена для руководителей и специалистов хозяйств, научных сотрудников институтов, аспирантов и студентов, обучающихся по специальности «Зоотехния».

УДК 636.2.034.:636.083.312.3; ББК 46.0; ISВN 978-5-98914-185-2; 148 стр. ПО ВОПРОСАМ ПРИОБРЕТЕНИЯ ОБРАЩАТЬСЯ ПО АДРЕСУ:

150042, Г. ЯРОСЛАВЛЬ, ТУТАЕВСКОЕ ШОССЕ, 58, ФГБОУ ВО ЯРОСЛАВСКАЯ ГСХА e-mail: e.bogoslovskaya@yarcx.ru 